\title{
PENINGKATAN KETERAMPILAN PEMECAHAN MASALAH (PROBLEM SOLVING) CALON GURU BIOLOGI MELALUI PEMBELAJARAN BERBASIS KEARIFAN LOKAL
}

\author{
Titin*, Yokhebed \\ Dosen pendidikan Biologi FKIP Universitas Tanjungpura \\ *E-mail: titinbasuki@ rocketmail.com
}

\begin{abstract}
The learning process with the utilization of biodiversity, social culture and environment one of them can grow problem solving skills. For that needs an effort to improve problem solving skills by making local wisdom as the reference for the learning. The research methods of this study were qualitative with lesson study form, with the stage plan, do and see, implemented in two cycles. The subject of the research was the second semester students of academic year 2015/2016 who follow environmental knowledge course. Aspects measured in cycle 1 and 2 were skills for evaluating problems, managing problems, making decisions, problems solving and making decisions. The result showed an increase in each aspect of skills that is $0,40,0,41,0,56,0,46$, and 1,25. Thus, overall the highest increase in making decisions aspects. While the average problem solving skills of student cycle 1 is 2,21 and increased to 2,84 in cycle 2. Thus it can be concluded that local wisdom based learning improves the problem solving skills of biology teacher candidates.
\end{abstract}

Keyword: local wisdom, problem solving skills, biology teacher candidates.

Asas pengembangan
pendidikan seperti yang di
canangkan oleh UNESCO meliputi
empat pilar pendidikan yaitu
learning to know, learning to do,
learning to be dan learning to live
together (Tim Belmawa Dikti, 2014).
Makna dari pembelajaran bukan
hanya untuk transfer ilmu
pengetahuan dari dosen ke
mahasiswa, namun pembelajaran
yang diarahkan pada berbagai
kemampuan dan keterampilan yang
diperlukan sebagai respon dari

partisipasi dalam perkembangan
sosial yang dinamis. Salah satunya
adalah keterampilan untuk mengelola
dan mencari pemecahan konflik,
mengambil keputusan, inisiatif dan
kesiapan mengambil resiko. Hal ini
pula yang tertuang dalam deskripsi
umum kerangka kualifikasi nasional
Indonesia (KKNI) pada level 6
(jenjang sarjana) pada bagian
deskripsi umum yaitu mampu
mengaplikasikan bidang keahliannya
dan memanfaatkan ilmu
pengetahuan, teknologi, dan/atau 
seni pada bidangnya dalam penyelesaian masalah serta mampu beradaptasi terhadap situasi yang dihadapi (Perpres No 8 tahun 2012).

Dengan demikian, peran dosen dalam memfasilitasi proses pembelajar-an sangat perlu mengembangkan berbagai keterampilan, sikap dan pengetahuan yang diperlukan dalam menghadapi era globalisasi ini. Salah satu keterampilan yang dapat di kembangkan yaitu keterampilan dalam menyelesaikan masalah/problem solving serta mampu beradaptasi terhadap situasi yang dihadapi.

Pemecahan masalah adalah suatu cara atau stategi untuk mewujudkan harapan sesuai dengan prosedur yang baik dan benar (Febriyanti dan Irawan. 2017). Untuk itu keterampilan pemecahan masalah dapat juga dikatakan sebagai keterampilan individu dalam menggunakan proses berfikirnya untuk memecahkan masalah.

Keterampilan pemecahan masalah sangat dibutuhkan dalam menghadapi berbagai situasi baik dalam kehidupan sehari-hari dan pekerjaan. Namun berdasarkan hasil observasi awal pada mahasiswa semester 2 pendidikan Biologi FKIP UNTAN tahun akademik 2015/2016, diketahui dalam memecah-kan suatu permasalahan yang diberikan dosen berupa tugas penyelidikan pada mata kuliah pengetahuan lingkungan didapatkan data yaitu diantara 29 orang mahasiswa hanya 5 orang mahasiswa atau sekitar $17,24 \%$ yang dapat mengevaluasi kendalahambatan dari proses pemecahan masalahnya. Selain itu pada proses pemecahan masalah yang selama ini dilatihkan pada mahasiswa, mereka masih kesulitan mengiden-tifikasi masalah-masalah yang bersifat open ended. Pembelajaran yang selama ini dilaksanakan yaitu menggunakan metode ceramah dan diskusi. Namun masih cenderung berpusat pada buku (text book) dan kurang menggali nilai-nilai kearifan lokal sebagai acuan dalam pembelajaran. Kearifan lokal dalam masyarakat sangat berpotensi dijadikan acuan dalam pembelajaran dengan memunculkannya sebagai masalah yang bersifat open ended. Masalah yang berifat open ended tersebut dapat mengembangkan keterampilan pemecahan masalah karena mengharuskan mahasiswa untuk menyelesaikan masalah. Pemecahan masalah dilakukan dengan berbagai solusi dari berbagai disiplin ilmu dimulai dari mengidentifikasi masalah hingga mengevaluasi proses pemecahan masalah.

Suastra dalam Suastra (2010) mengatakan bahwa nilai-nilai yang dianut oleh masyarakat asli yang penuh dengan nilai-nilai kearifan (local genius) diabaikan dalam pembelajaran khususnya dalam pembelajaran sains di sekolah. Dengan demikian, pembelajaran sains menjadi "kering" dan kurang bermakna bagi siswa. Demikian halnya yang terjadi pada pembelajaran di kampus. Padahal kearifan lokal sangat penting terintegrasi dalam pembelajaran mengingat keberadaan nilai-nilai lokal semakin terkikis akibat pengaruh globalisasi. Menggali dan menanamkan kembali kearifan lokal melalui pembelajaran merupakan bagian dari upaya membangun identitas bangsa dan dapat dijadikan 
sebagai sarana dalam menyeleksi pengaruh budaya yang datang dari luar. Nilai-nilai positif yang terkandung di dalam kearifan lokal baik untuk dikembangkan dalam pembentukan karakter dan identitas bangsa. Kearifan lokal adalah pandangan hidup dan ilmu pengetahuan serta berbagai strategi kehidupan yang berwujud aktivitas yang dilakukan oleh masyarakat lokal dalam menjawab berbagai masalah dalam pemenuhan kebutuhan mereka. Pembelajaran dengan mengangkat kearifan lokal dapat mengembangkan karakter dan keterampilan berpikir pemecahan masalah melalui strategi pemecahan masalah yang diangkat dari masalah lokal.

Kearifan lokal terdiri dari dua kata, yaitu kearifan (wisdom) dan lokal (local). Wisdom (kearifan) memiliki arti yang sama dengan kebijaksanaan, sedangkan local (lokal) memiliki arti setempat. Menurut Sartini dalam Murdiono (tanpa tahun) menyatakan bahwa local wisdow atau kearifan lokal adalah gagasan-gagasan bijaksana, penuh kearifan, memiliki nilai baik yang diikuti dan tertanam pada anggota masyarakat yang dimiliki daerah setempat (lokal).

Menurut Rahyono dalam Fajarini (2014), kearifan lokal merupakan kecerdasan manusia yang dimiliki oleh etnis tertentu yang diperoleh melalui pengalaman masyarakat. Kearifan lokal yang dimaksud adalah hasil dari masyarakat tertentu yang diperoleh dari pengalaman masyarakat dan belum tentu dialami oleh masyarakat yang lain. Kearifan lokal yang dimaksud dalam penelitian ini adalah gagasan-gagasan dari masyarakat Kalimantan Barat yang memiliki nilai-nilai baik yang diikuti, seperti pengelolaan hutan adat oleh desa setempat dan hubungannya dalam menjaga ekosistem hutan, pengaturan penangkapan ikan di perairan dan hubungannya dalam menjaga ekosistem sungai, serta berbagai pengelolaan lingkungan yang erat kaitannya dengan alam/ lingkungan hidup.

Keterampilan pemecahan masalah menurut Syafii and Yasin, ( 2013)... is the highest and more complex level of learning. The thinking process in problem solving requires skills to process and organize the obtained information to utilize it in the problem solving process. Possessing a problem solving skill means that the person is able to think critically, logically and creatively. Penyelesaian atau pemecahan masalah adalah bagian dari proses berpikir. Proses berfikir berupa kognitif tingkat tinggi yang memerlukan modulasi dan kontrol lebih dari keterampilan-keterampilan rutin atau dasar disebut juga pemecahan masalah. Menurut Firdaus (2009) pemecahan masalah merupakan kemampuan dasar yang harus dikuasai oleh siswa. Tuntutan akan kemampuan pemecahan masalah dipertegas secara eksplisit dalam kurikulum tersebut yaitu, sebagai kompetensi dasar yang harus dikembangkan dan diintegrasikan pada sejumlah materi yang sesuai. Keterampilan pemecahan masalah yang dimaksud dalam penelitian ini keterampilan memproses dan mengorganisasi informasi melalui proses pemecahan masalah melalui tahapan 
mengidentifikasi masalah, mengeksplorasi, menentukan tujuan, menentukan alternatif, menyeleksi alternatif, implementasi alternatif, dan mengevaluasi.

$$
\text { Kearifan lokal terbentuk }
$$
sebagai keunggulan budaya masyarakat setempat maupun kondisi geografis dalam arti luas. Kearifan lokal merupakan produk budaya masa lalu yang patut secara terusmenerus dijadikan pegangan hidup. Di dalam nilai-nilai lokal tersebut mengandung nilai yang sangat universal.

Kearifan lokal ini sudah sesuai dengan UU RI No. 23 Tahun 1997 tentang pengelolaan lingkungan hidup. Dalam UU tersebut didefinisikan tentang pengelolaan lingkungan hidup, yaitu upaya terpadu untuk melestarikan fungsi lingkungan hidup yang meliputi kebijaksanaan penataan, pemanfaatan, pengembangan, pemeliharaan, pemulih-an, pengawasan, dan pengendalian lingkungan hidup. Pembelajaran berbasis kearifan lokal diharapkan dapat meningkatkan keterampilan pemecahan masalah pada mahasiswa

\section{METODE}

Penelitian ini dilaksanakan pada mahasiswa Program Studi Pendidikan Biologi semester II Fakultas Keguruan dan Ilmu Pendidikan (FKIP) Universitas Tanjungpura (UNTAN) Pontianak Tahun Akademik 2016/2017 pada mata kuliah Pengetahuan Lingkungan. Jumlah mahasiswa yang terlibat dalam pembelajaran berjumlah 34 orang mahasiswa.
Lokasi penelitian dilaksanakan di kampus FKIP UNTAN berada di Jalan Prof. Dr. Hadari Nawawi Pontianak. Penelitian akan dilaksanakan pada bulan April sampai dengan Mei 2017.

Penelitian ini merupakan Penelitian kualitatif melalui kegiatan lesson study. Kegiatan Lesson study yang dilakukan secara kolaboratif bersama sekelompok guru bertujuan untuk meningkatkan proses dan hasil pembelajaran yang dilaksanakan. Lesson study merupakan salah satu alternatif yang digunakan untuk mengatasi masalah dalam kegiatan pembelajaran (Rusman, 2010). Alur dalam penelitian terdiri atas tiga tahap yaitu; tahap perencanaan (plan), tahap implementasi (do), dan tahap refleksi (see). Adapun tahapan yang dilakukan yakni:

\section{Tahapan Perencanaan (Plan)}

Dalam tahap perencanaan, tim dosen pengampu mata kuliah pengetahuan lingkungan berkolaborasi untuk menyusun RPS (Rencana Pembelajaran Semester) yang mencerminkan pembelajaran berbasis kearifan lokal. Perencanaan diawali dengan kegiatan menganalisis kebutuhan dan permasalahan yang dihadapi dalam pembelajaran, seperti tentang: kompetensi dasar, cara membelajarkan mahasiswa, mengatasi kekurangan fasilitas dan sarana belajar, dan sebagainya, sehingga dapat ketahui berbagai kondisi nyata yang akan digunakan untuk kepentingan pembelajaran. Selanjutnya, secara bersama-sama dicari solusi untuk memecahkan permasalahan yang ditemukan. 


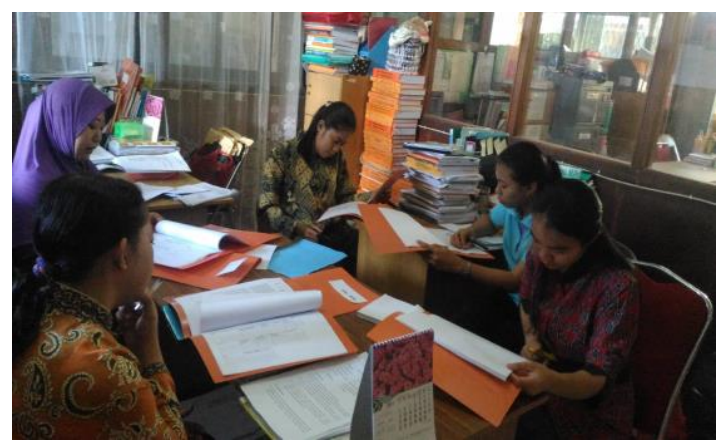

(a)

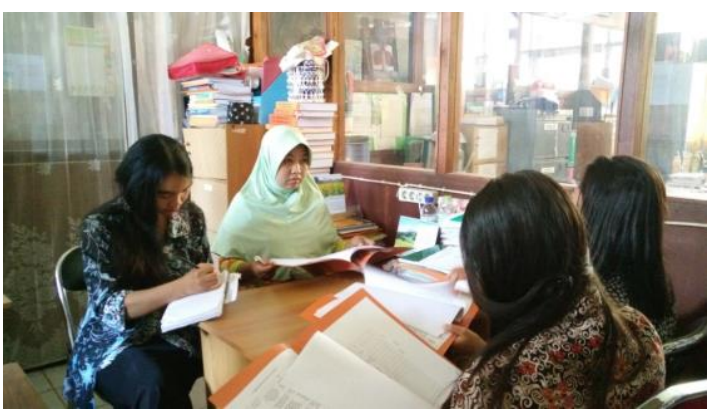

(b)

Gambar 1. Kegiatan Plan (a) siklus 1

(b) siklus 2

\section{Tahapan Pelaksanaan (Do)}

Pada tahapan yang kedua, terdapat dua kegiatan utama yaitu: (1) kegiatan pelaksanaan pembelajaran yang dilakukan oleh salah seorang dosen pengampu mata kuliah untuk mempraktikkan SAP yang telah disusun bersama, dan (2) kegiatan pengamatan atau observasi yang dilakukan oleh observer.

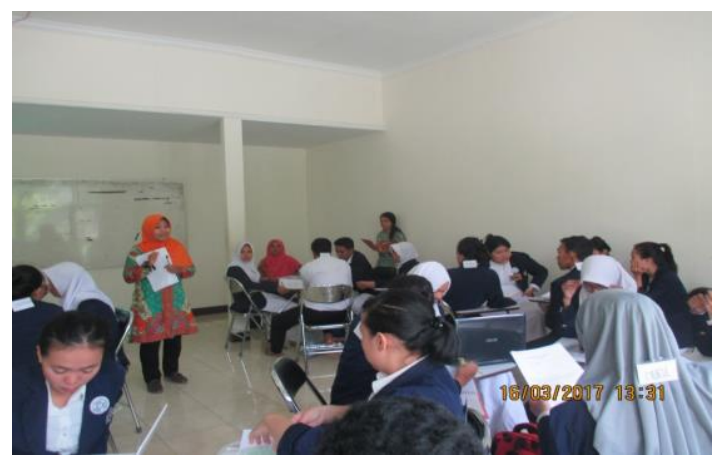

(a)

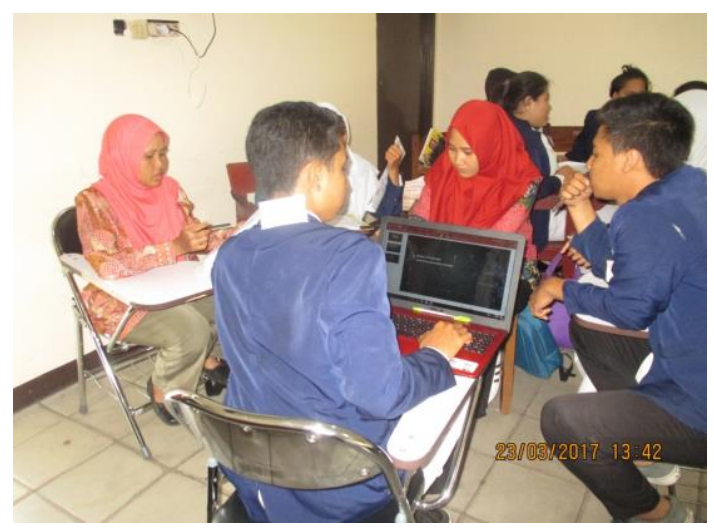

(b)

Gambar 2. Kegiatan Do (a) siklus 1

(b) siklus 2

\section{Tahapan Refleksi (See)}

Tahapan ketiga refleksi (see) merupakan tahapan upaya perbaikan proses pembelajaran. Kegiatan refleksi dilakukan dalam bentuk diskusi yang diikuti dosen dan seluruh observer. Kegiatan diskusi yang dilakukan dimulai dengan dosen menyampaikan keadaan yang dirasakan selama proses pembelajaran dan kesulitan yang dialami oleh dosen saat praktik pembelajaran berlangsung. Selanjutnya, semua observer menyampaikan tanggapan atau saran terhadap proses pembelajaran yang telah dilaksanakan. Focus kegiatan refleksi adalah interaksi mahasiswa 
dalam proses pembelajaran terkait keterampilan pemecahan masalah.

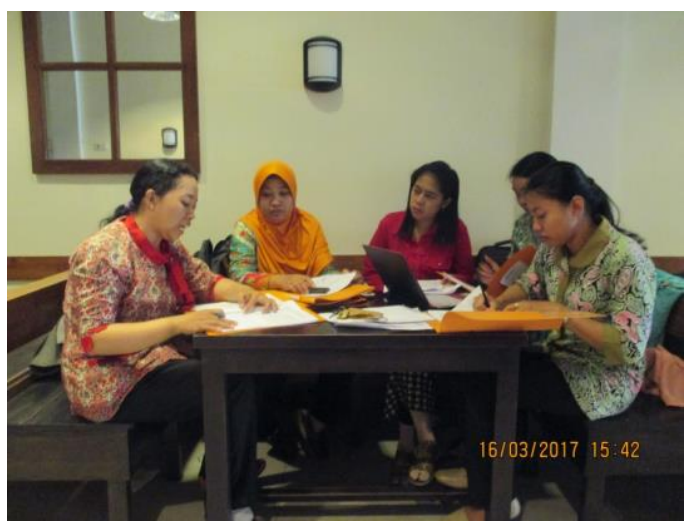

(a)

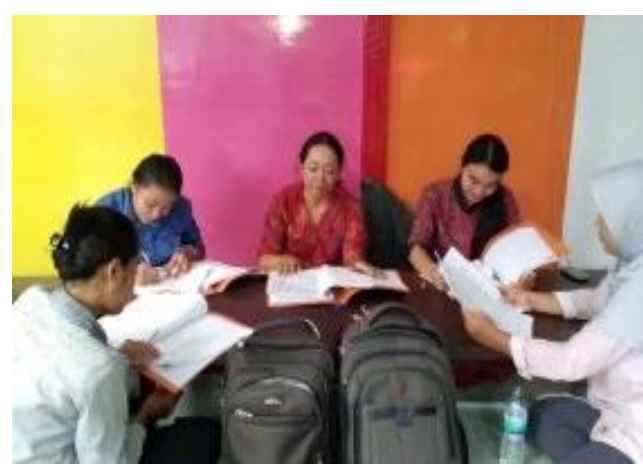

(b)

Gambar 3. Kegiatan See (a) siklus 1

(b) siklus 2

Teknik pengumpulan data dalam penelitian ini berupa non tes. Teknik non tes yang digunakan berupa lembar observasi dan angket. Hasil pengamatan dari observasi tersebut dinyatakan secara kuantitatif.

Angket berisi sejumlah pertanyaan-pertanyaan yang pilihan jawabannya telah disediakan (angket terstruktur). Responden diminta untuk memilih satu jawaban yang sesuai dengan karakteristik dirinya dengan cara memberi tanda silang sedangkan lembar observasi berbentuk checklist. Bentuk skala yang digunakan yakni skala likert.
Selain angket dan observasi, teknik pengumpulan data juga menggunakan studi dokumentasi.

Analisis data pada penelitian ini selain menggunakan pendekatan kuantitatif juga menggunakan pendekatan analisis kualitatif. Analisis kualitatif terdiri atas tiga alur kegiatan yang terjadi secara bersamaan yaitu reduksi data, penyajian data, penarikan kesimpulan dan verifikasi data. Kegiatan ini dilakukan secara terus menerus selama dan setelah pengumpulan data di lapangan (Milles dan Huberman, 2007). Analisis interaktif terdiri atas 3 komponen kegiatan yang saling terkait satu sama lain: reduksi data, display data, dan penarikan kesimpulan.

Analisis data dilakukan sepanjang proses lesson study. Kegiatan lesson study dilakukan secara berjenjang. Setelah tahapan plan, do dan see yang dilakukan maka dapat ditarik kesimpulan sementara di akhir siklus pertama dan diperoleh kesimpulan terakhir pada siklus kedua.

\section{HASIL DAN PEMBAHASAN}

Berdasarkan hasil pelaksanaan lesson study yang telah dilaksanakan maka diperoleh hasil sebagai berikut:

Tabel 1. Skor dan rata-rata aspek keterampilan pemecahan masalah per siklus

\begin{tabular}{cccc}
\hline Siklus & $\begin{array}{c}\text { Jumlah } \\
\text { skor }\end{array}$ & $\begin{array}{c}\text { Rata- } \\
\text { rata } \\
\text { skor }\end{array}$ & $\begin{array}{c}\text { Skor } \\
\text { maksimal }\end{array}$ \\
\hline 1 & 70.8 & 2.21 & \multirow{2}{*}{4} \\
\hline 2 & 90.8 & 2.84 & \\
\hline
\end{tabular}


Berdasarkan data pada Tabel 1 di atas terdapat selisih rata-rata skor keterampilan pemecahan masalah yaitu sebesar 0.63. Keterampilan pemecahan masalah pada siklus 2 lebih tinggi dikarenakan mahasiswa sudah mulai terbiasa dengan pembelajaran berbasis kearifan lokal. Pembelajaran berbasis kearifan lokal merupakan hal yang baru bagi mahasiswa sehingga pada siklus 1 masih ditemukan beberapa mahasiswa yang terlibat kebingungan dan belum dapat mengikuti dengan baik proses pembelajaran yang dilaksanakan. Materi pembelajaran yang dikembangkan dari kearifan lokal memiliki makna dan relevansi tinggi terhadap pemberdayaan hidup mahasiswa secara nyata, berdasarkan realitas yang dihadapi.

Keterampilan pemecahan masalah dalam penelitian ini terdiri atas 5 aspek (modifikasi Syafii dan Yasin, 2013) dapat dilihat pada tabel dibawah ini yaitu:

Tabel 2. Aspek Keterampilan Pemecahan Masalah

No Aspek Keterampilan Pemecahan Masalah

\begin{tabular}{ll}
\hline 1 & Mengevaluasi masalah \\
2 & Mengelola masalah \\
3 & Pengambilan keputusan \\
4 & Penyelesaian masalah \\
5 & Mengevaluasi kesimpulan \\
\hline
\end{tabular}

Berdasarkan hasil observasi pada siklus 1 dan 2 dapat dilihat pada Gambar 4.

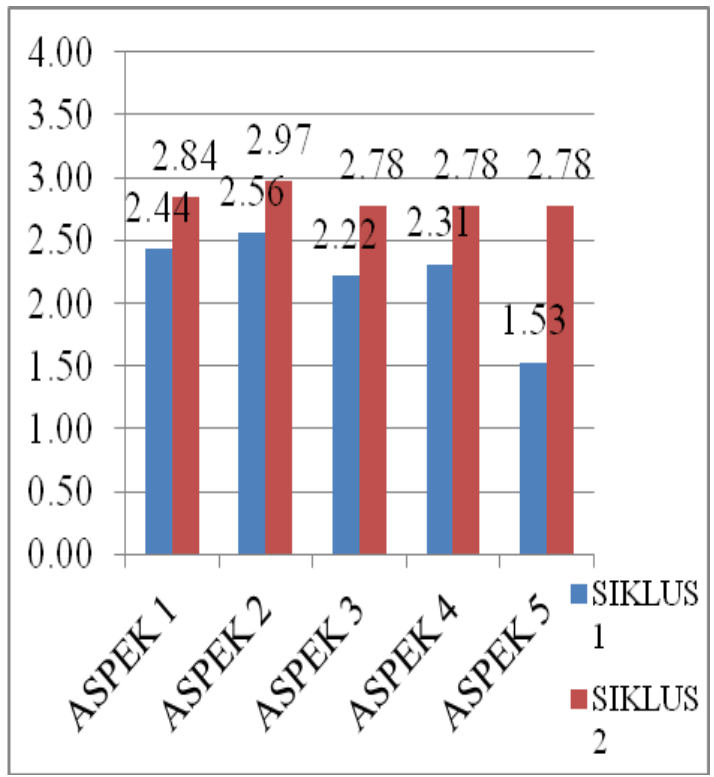

Gambar 4. Keterampilan Pemecahan Masalah per Aspek

Berdasarkan Tabel 1. diperoleh bahwa terjadi peningkatan rata-rata skor keterampilan pemecahan masalah sebesar 0,63. Adanya peningkatan pada masingmasing-masing aspek keterampilan yaitu sebesar 0,41, 0,41, 0,56, 0,46 dan 1,25. Peningkatan ini terjadi pada siklus 1 ke siklus 2 .

Proses

pembelajaran menggunakan kearifan lokal pada konten materi pembelajaran yang dikembangkan memiliki makna dan relevansi tinggi terhadap pemberdayaan hidup mahasiswa secara nyata, berdasarkan realitas yang dihadapi.

Hal ini sesuai dengan penelitian yang telah dilakukan Ismail dan Atan (2011) menyatakan bahwa pelajar harus mampu merancang dan melaksanakan strategi serta memiliki pengetahuan 
tentang prosedur penyelesaiannya. Hal ini berarti siswa harus menentukan strategi yang dapat digunakan dalam penyelesaian masalah.

Pada siklus 1 materi yang dibahas yaitu mengenai tipe-tipe ekosistem. Pada materi ini mahasiswa ditugaskan untuk mengidentifikasi ekosistem yang ada disekitar tempat tinggal mereka. Berdasarkan hasil identifikasi diperoleh beberapa ekosistem alami dan buatan diantaranya ekosistem sungai, ekosistem lahan gambut, ekosistem hutan hujan tropis, serta ekosistem buatan lainnya. Berdasarkan materi tersebut terdapat beberapa kearifan lokal yang dibahas yaitu tentang pemanfaatan ekosistem untuk kehidupan masyarakat disekitar misalnya pada pemanfaatan ekosistem pantai di Mempawah kabupaten Pontianak untuk wisata dan bakau yang terdapat disekitar pantai dijadikan tempat mencari ikan, kepiting dan udang. Hal ini menimbulkan pemahaman bagi mahasiswa mengenai upaya penyesuaian masyarakat terhadap alam untuk pemenuhan kebutuhan hidupnya yang merupakan bagian dari kearifan lokal. Menurut Destalia dkk (2014) Pembelajaran Berbasis Masalah (PBM) merupakan suatu model pembelajaran yang didasarkan pada banyaknya permasalahan yang membutuhkan penyelidikan autentik yakni penyelidikan yang membutuhkan penyelesaian nyata dari permasalahan yang nyata. Hal ini melatihkan keterampilan analitis bagi mahasiswa terkait karakteristik, pemanfaatan dan ancaman pada ekosistem tersebut.
Pada siklus 2 materi yang dibahas yaitu mengenai masalah kependudukan, pembahasan mengenai materi ini dimulai dengan mengidentifikasi masalah kependudukan yang timbul misalnya pertambahan penduduk di Kalimantan Barat. Penduduk yang bertambah terus setiap tahun menghendaki penyediaan sejumlah kebutuhan atas "pangan, sandang dan papan (rumah)". Sementara itu ruang muka bumi tempat manusia mencari nafkah tidak bertambah luas. Perluasan lapangan usaha itulah yang pada gilirannya menyebabkan eksploitasi lingkungan secara berlebihan dan liar. Konten kearifan lokal dibahas pada dampak dan upaya mengatasi eksploitasi lingkungan. Pada masyarakat adat di Kalimantan Barat khususnya suku dayak masih memperhatikan perilaku manusia terhadap alam dengan diberlakukannya larangan atau pantang merusak hutan adat. Dengan demikian mahasiswa dibimbing untuk menemukan solusi dan memilih alternatif solusi yang tepat dari ancaman tersebut. Kemampuan yang demikian melatih mahasiswa untuk berpikir kreatif sebagai bentuk keterampilan pemecahan masalah. Berpikir analitis mendominasi dalam pemecahan masalah, di mana banyak kemungkinan penyebab harus diidentifikasi dan dianalisis untuk menemukan penyebabnya.

Berdasarkan Gambar 4 dapat dilihat aspek mengevaluasi kesimpulan merupakan aspek yang paling tinggi peningkatannya dari siklus 1 ke siklus 2. Berdasarkan hasil observasi pada siklus 1, mahasiswa masih sebagian belum dapat melakukan mengevaluasi 
kesimpulan dari berbagai alternative solusi yang telah mereka pilih. Berdasarkan hasil refleksi diperoleh informasi bahwa mahasiswa masih belum bisa menentukan alternatif yang benar-benar sesuai karena kurangnya keaktifan mahasiswa mencari dukungan literatur. Refleksi yang dilakukan pada siklus 2 untuk perbaikan dalam proses pembelajaran yakni mahasiswa diberi tugas untuk mencari literatur yang mendukung materi, sehingga pada saat proses pembelajaran sudah dapat digunakan sebagai acuan untuk menganalisis beberapa solusi yang tepat.

\section{SIMPULAN DAN SARAN Simpulan}

Berdasarkan hasil penelitian disimpulkan telah dilaksanakan plan, do dan see pada kegiatan Lesson study siklus 1 dan 2 sebagai berikut:

1. Adanya peningkatan pada masing-masing-masing aspek keterampilan yaitu sebesar 0,41 , $0,41, \quad 0,56, \quad 0,46$ dan 1,25. Dengan demikian secara keseluruhan peningkatan tertinggi pada aspek mengevaluasi kesimpulan.

2. Rata-rata keterampilan pemecahan masalah siklus 1 sebesar 2.21 dan mengalami peningkatan menjadi 2.83 pada siklus 2.

3. Pembelajaran berbasis kearifan lokal meningkatkan keterampilan pemecahan masalah (problem solving) calon guru biologi.

\section{Saran}

Berdasarkan hasil penelitian dapat disarankan pada tahap pelaksanaan pembelajaran diperlukan bimbingan secara individual terutama pada tahap membimbing investigasi kelompok. Hal ini disebabkan perbedaan gaya belajar mahasiswa dan motivasi yang berbeda. Sehingga disarankan penelitian selanjutnya dapat melihat pengaruh motiivasi dan gaya belajar yang berbeda terhadap pembelajharan dengan model pembelajaran berbasis masalah.

\section{DAFTAR PUSTAKA}

Destalia, Lendy; Suratno; Aprilya H Sulifah. (2014). Peningkatan Keterampilan Pemecahan Masalah dan Hasil Belajar Melalui Penerapan Pembelajaran Berbasis Masalah (PBM) Dengan Metode Eksperimen Pada Materi Pencemaran Lingkungan. Jurnal @ Pancaran, Vol. 3 No. 4, 213224

Fajarini, Ulfah. (2014). Peranan Kearifan Lokal dalam Pendidikan Karakter. Jurnal Sosio Didaktika. Vol. 1 No. 2, 124.

Febriyanti, Chatarina; Irawan, Ari. (2017). Meningkatkan Kemampuan Pemecahan Masalah Dengan Pembelajaran Matematika Realistik. Jurnal Matematika dan Pendidikan Matematika. Vol. 6 No. 1, 31-41

Firdaus, Ahmad. (2009). Kemampuan Pemecahan Masalah Matematika. Retrieved Mei 24, 2016, from https://madfirdaus.wordpress.co $\mathrm{m}$ 
86 Jurnal Pendidikan Matematika dan IPA Vol. 9 No. 1 Januari 2018: 77-86

Ismail, Sarimah; Atan, Abreza. (2011). Aplikasi Pendekatan Penyelesaian Masalah Dalam pengajaran Mata Pelajaran Teknikal dan Vokasional di Fakulti Pendidikan UTM. Journal of Educational Psychology and Counseling. Vol. 2 No. 1, 113-144.

Milles, Matthew.B. and Huberman, A.Michael. (2007). Analisis Data Kualitatif. Jakarta: UPI

Murdiono, M. (Tanpa tahun). Strategi Pembelajaran Kewarganegaraan Berbasis Kearifan Lokal. Retrieved Mei 20, 2016, from http://staff.uny.ac.id/sites/defaul t/files/132304487/B7MAKALAH \%2OSEMNASLEMLIT\%20UNY_0.pdf

Peraturan Presiden Republik Indonesia No.8 Tahun 2012 Tentang Kerangka Kualifikasi Nasional Indonesia.

Rusman. (2010). Model-model Pembelajaran. Jakarta: Rajawali Press.

Suastra, W.I. (2010). Model Pembelajaran Sains Berbasis Budaya Lokal Untuk Mengembangkan Kompetensi Dasar Sains Dan Nilai Kearifan Lokal di SMP. Jurnal Pendidikan Dan Pengajaran Vol, 43 No. 2.

Syafii, W dan Yasin, R.M. (2013). Problem Solving Skills and Learning Achievements through Problem-Based Module in teaching and learning Biology in High School. Asian Social 